\title{
Spatial Variability Mapping of Soil Nutrient through Geo-informatics Technology
}

\author{
Hena Parveen ${ }^{1}$, M. P. Singh ${ }^{2}$, S. S. Prasad ${ }^{2}$, Ajeet Kumar ${ }^{1}$, \\ Dhanajay Kumar $^{1}$, Raju Kumar ${ }^{1}$ and Sunil Kumar ${ }^{1 *}$ \\ ${ }^{1}$ Department of Soil Science and Agricultural Chemistry, Bihar Agricultural University, \\ Sabour Bhagalpur, Bihar, India \\ ${ }^{2}$ Department of Soil Science, Dr.RajendraPrasad Central Agricultural University, \\ Pusa (Samastipur), Bihar, India \\ *Corresponding author
}

\section{A B S T R A C T}

\section{Keywords}

Spatial variability,

Thematic maps,

Nutrient index,

Productive Index

Article Info

Accepted:

10 October 2020

Available Online:

10 November 2020
The Knowledge of spatial-variability is critical for site specific nutrient management in soil fertility. Soil sample (149) were gotten from surface from 10 selected sites for preparing precise digital maps using point, line and polygon tools of the GIS (TNTmips 2010) software. Soil spatial variability typically defines variation in soil properties in surface soil such as fertility, $\mathrm{pH}, \mathrm{EC}$, soil organic carbon $(\mathrm{OC})$, free $\mathrm{CaCO}_{3}$, mineralizable $\mathrm{N}, \mathrm{P}_{2} \mathrm{O}_{5}, \mathrm{~K}_{2} \mathrm{O}$ and $\mathrm{S}$. In this study 149 soil samples were collected from the Rajendra Agricultural University, Pusa Farm, and based on the score of nutrients, corresponding thematic maps were drawn up. The thematic soil maps clearly revealed the distribution of different physico-chemical characteristics and available nutrients status which were assigned appropriate classes - low, medium and high or sufficient /deficient. The maximum spatial distribution of soil $\mathrm{pH} 8.0$ to 8.5 (41.84\%), soil EC 0.5 to $1 \mathrm{dS} \mathrm{m}^{-1}$ (49.31\%), organic carbon 0.50 to $0.75 \%(60.43 \%)$, mineralizable soil nitrogen $<250 \mathrm{~kg} \mathrm{ha}^{-}$ ${ }^{1}(86.27 \%)$, available phosphorus 25 to $50 \mathrm{~kg} \mathrm{ha}^{-1}(71.06 \%)$, potassium 125 to $300 \mathrm{~kg} \mathrm{ha}^{-1}$ $(87.71 \%)$, available $\mathrm{S}<13 \mathrm{mg} \mathrm{kg}^{-1}(80.48 \%)$ and Free $\mathrm{CaCO}_{3} 20-30 \%$ (55.2\%). Under multi major nutrient deficient soils, low in nitrogen and potassium were in $36.74 \%$ area and low phosphorus and potassium were in $19.78 \%$ area. Nutrient Index calculated for the major nutrients N, P and K were 1.416, 1.893 and 1.678, respectively. Productivity Index (PI) was estimated on the basis of soil texture available $\mathrm{N}, \mathrm{P}_{2} \mathrm{O}_{5}$ and $\mathrm{K}_{2} \mathrm{O}$ showed spatial distribution of $90.27 \%$ area with low PI, 9.57\% area with medium PI and $0.15 \%$ with high PI.

\section{Introduction}

Spatial distribution patterns of soil properties, techniques such as conventional statistics and geo-statistics were widely applied (Saldana $e t$ al., 1998, McGrath and Zhang, 2003,
Sepaskhah et al., 2005, Liu et al., 2006), and based on the theory of a regionalized variable (Matheron1963), geo-statistics provides advanced tools to quantify the spatial features of soil parameters and allows for spatial interpolation to be conducted. The research 
benefits of the geographic information systems (GIS) approach were illustrated by many ecological and agricultural studies (Bradshaw and Muller 1998, Wang et al., 2006).

A better understanding of the spatial variability of soil nutrients in this region critical for refining farm management practices and for enhancing sustainable land use (McGrath and Zhang, 2003). Soil testing provides information on the nutrient availability in soils, on this basis an effective fertilizer recommendations are generated for optimize crop yield.

Soil fertility maps are intended to illustrate nutrient requirements based on soil fertility status (and adverse soil conditions which need improvement) to achieve better crop yield. Clearly, a soil fertility map for a specific region can be highly useful in directing growers, manufacturers and planners (associated with fertilizer marketing and distribution) to assess the requirements of various fertilizers in a season/year and to create forecasts for increased demand based on crop trend and intensity.

The goal of this work was to study the spatial variability of soil nutrients and to explore how soil nutrients are influenced by natural environmental factors and anthropogenic land use of the agricultural soils of Rajendra Agricultural University, Pusa Farm.

This objective was achieved by using geostatistical methods and GIS to find soil reaction $(\mathrm{pH})$, Soil Electrical Conductivity (EC, dS/m), Organic Carbon (\%), Mineralizable Soil Nitrogen (kg ha $\left.{ }^{-1}\right)$ Available Phosphorus $\left(\mathrm{kg} \mathrm{ha}^{-1}\right)$ Available Potassium $\left(\mathrm{kg} \mathrm{ha}^{-1}\right)$ Available Sulphur (mg $\mathrm{kg}^{-1}$ ) Soil free $\mathrm{CaCo}_{3}(\%)$ spatial distribution characteristics.

\section{Materials and Methods}

The study area comprising of Samastipur of Rajendra Agricultural University, The entire area of pusa farm 485 ha. The area is U shaped South-West lap of river BurhiGandak at an altitude of $52.0 \mathrm{~m}$.Pusa comes under the North-West alluvial plain (Zone-1) of Bihar. Ps usa Farm lies between $25^{\circ} 58^{\prime} 54^{\prime \prime} \mathrm{N}$ to $25^{\circ}$ $59^{\prime} 28.91^{\prime \prime} \mathrm{N}$ latitude and $85^{\circ} 40^{\prime} 25^{\prime \prime} \mathrm{E}$ to $85^{\circ}$ 41' 27.88' E longitude and depicted on survey of India's topo-sheet number $72 \mathrm{G} 9$ of scale 1:50,000.

The soil of the study area is young alluvium and calcareous with patches of salt affected soil having different amount of free $\mathrm{CaCO}_{3}$ content which varies between $5-40 \%$ or more. Calcium carbonate is present in a soft precipitated amorphous form, presumably of the size of silt $(0.02$ to $0.002 \mathrm{~mm})$ and below. The range of $\mathrm{pH}$ in the surface soils were recorded from 7.8 to 9.2 .

Map obtained from Google Earth has georeferenced in GIS setting by using six identified locations under Pusa farm boundary. The exact latitude and longitude WF5were embedded and saved in image. The Digital boundary of Farm was opened in Geometry and Re-projected to change output projection in meter. For this purpose UTM zone $45 \mathrm{~N}(\mathrm{CM}$ 87E) projection selected and processed. Than after Digitalization was done by using of GIS software's point, line and polygon tools. Pusa Farm's 200 x 200 m grid map was compiled using the GIS program and farm was divided into 164 grids as shown in Map1.

The results of available nutrient were tabulated with Unique ID in Microsft Excel.csv (Comma Separated Value) format and linked to the soil sampling GPS coordinate points by import action of the GIS software. 
All 149 Surface soil samples (0-15 cm depth) were collected from the grid cell at random, and were air dried in shade and grounded to pass through a $2 \mathrm{~mm}$ sieve and held separately a4 9long with the proper labels in polythene bags. The exact position of the sample was reported using a handheld GPS receiver. All processed soil samples were analyzed for estimation of various soil parameter viz., $\mathrm{pH}$, Electrical Conductivity (EC), Soil Organic Carbon (OC), free $\mathrm{CaCO}_{3}$, available $\mathrm{N}, \mathrm{P}_{2} \mathrm{O}_{5}, \mathrm{~K}_{2} \mathrm{O}$ and Sulphur. Soil $\mathrm{pH}$ was determined by potentiometric method in 1:2 soil-water suspension and Electrical conductivity was determined by using Conductivity Bridge in 1:2 soil-water extract, it is expressed as $\mathrm{dSm}^{-1}$. Walkely and Black's wet oxidation method was used to determine the organic carbon content from finely ground soil and Available nitrogen was estimated by alkaline $\mathrm{KMnO}_{4}$ method described by Jackson. The amount of available phosphorus was estimated by using sodium bicarbonate $(0.5 \mathrm{M})$ at $\mathrm{pH} 8.5$ (Olsen's reagent) and Spectrophotometer at wavelength of $660 \mathrm{~nm}$. Available potassium in soil was extracted by neutral normal ammonium acetate and estimation was by flame photometry. Free $\mathrm{CaCO}_{3}$ were determined by Rapid titration method using $\mathrm{N} \mathrm{HCl}$ and $\mathrm{N} \mathrm{NaOH}$. Available sulphur was extracted by $0.15 \% \mathrm{CaCl}_{2} \cdot 2 \mathrm{H}_{2} \mathrm{O}$ (Turbidimetric method).

The thematic maps thus prepared on the criteria described by Singh et al., 2006 and this map was classified into different classes' viz., high, medium and low or deficient/ sufficient. TNTmips 2010 with spatial analyst function of Arc GIS software was used to prepare soil fertility maps. Interpolation method employed was spline.

Interpolation had been handled by minimum curvature method which provided a geostatistic layer containing and after minimum curvature the fitting classes. The extent of area in low, medium and high category of nutrients was estimated on the basis of standard ratings.

\section{Multi Major Nutrient Deficiency Map}

Thematic map has been prepared in interpretation of the major nutrient $(\mathrm{N}, \mathrm{P}, \mathrm{K})$ deficient area in the farm for well management and advanced productivity. The available major nutrient content were classified into high, medium and low and grouped together. In such a way combination of 27 groups formed. Some of the groups had no value and so discarded.

The combination of at least low in two major nutrients were considered as deficiency sample and assigned a value from 1 to 4 . The remaining combinations were assigned a value of 5 .

Productivity Index (PI) estimated on the basis of soil texture, available $\mathrm{N}, \mathrm{P}_{2} \mathrm{O}_{5}$ and $\mathrm{K}_{2} \mathrm{O}$ showed spatial distribution with low, medium and high PI (Riquier et al., 1970).

Productivity Index $(\mathrm{PI})=$ T. N. $\mathrm{P}_{2} \mathrm{O}_{5} \cdot \mathrm{K}_{2} \mathrm{O}$

Where

$\mathrm{T}=$ Rating for soil texture taken as 100 for the texture suitable for growing various crop i.e Loamy, 80 for medium texture and 60 for coarse texture.

$\mathrm{N}=$ Rating for available $\mathrm{N}$, high $\mathrm{N}$ soils $=1$, medium $\mathrm{N}$ soils $=0.8$ and low $\mathrm{N}$ soils $=0.6$.

$\mathrm{P}_{2} \mathrm{O}_{5}=$ Rating for available $\mathrm{P}$, high $\mathrm{P}_{2} \mathrm{O}_{5}$ soils $=1$, medium $\mathrm{P}_{2} \mathrm{O}_{5}$ soils $=0.8$ and low $\mathrm{P}_{2} \mathrm{O}_{5}$ soils $=0.6$.

$\mathrm{K}_{2} \mathrm{O}=$ Rating for available $\mathrm{K}$, high $\mathrm{K}_{2} \mathrm{O}$ soils $=1$, medium $\mathrm{K}_{2} \mathrm{O}$ soils $=0.8$ and low $\mathrm{K}_{2} \mathrm{O}$ soils $=0.6$. 


\section{Results and Discussion}

The table 1 shows mean, range, standard deviation (SD) and coefficient of variation (CV) and thematic map of soil chemical properties and nutrient status of 149 samples collected in the working area.

\section{Hydrogen ions activity (pH)}

The soil $\mathrm{pH}$ value in the study area varies from 7.1 to 9.2 that show a neutral to highly alkaline soil $\mathrm{pH}$ with a mean and SD value of 8.2 and \pm 0.53 , respectively. The thematic soil reaction map (as shown in Map:2) clearly indicates its spatial distribution showing an area $41.84 \%$ with soil $\mathrm{pH} 8.0$ to 8.5 followed by an area $33.01 \%$ with $\mathrm{pH}>8.5$ and an area $25.15 \%$ with $\mathrm{pH}<8.5$. The spatial distribution of soil $\mathrm{pH} 8.0$ to 8.5 was observed in lowland and $\mathrm{pH}>8.5$ was observed in medium and upland region of the research area. Similar results were reported by Pandey (2012), NekeeSweta (2014) and Rupali (2014).

\section{Electrical conductivity (EC)}

The soil EC value in the study area varies from 0.14 to $2.75 \mathrm{dS} \mathrm{m}^{-1}$ with mean and SD value of 0.81 and \pm 0.45 , respectively. The thematic map of EC (As shown in Map: 3) clearly indicated its spatial distribution showing an area $49.31 \%$ with EC 0.5 to 1.0 $\mathrm{dS} \mathrm{m} \mathrm{m}^{-1}$ followed by an area $41.72 \%$ with EC > $1.0 \mathrm{dS} \mathrm{m} \mathrm{m}^{-1}$ and area $8.97 \%$ with EC $<0.5 \mathrm{dS}$ $\mathrm{m}^{-1}$.The spatial distribution of soil EC 0.5 to 1 $\mathrm{dS} \mathrm{m}^{-1}$ were observed in lowland, medium upland and Similar results was also reported by Pandey (2012), NekeeSweta (2014) and Rupali (2014).

\section{Organic Carbon Content}

The organic carbon content of Samastipur district's soil is very low it varies from 0.17 to $0.91 \%$ with a mean and SD value 0.53 and \pm
0.61 , respectively. The thematic map of soil organic carbon (as shown in Map: 4) clearly indicates its spatial distribution, showing an area $60.43 \%$ with organic carbon \% 0.50 to 0.75 followed by an area $38.40 \%$ with organic carbon $\%<0.5 \%$ and an area $1.17 \%$ with organic carbon $\%>0.75$. The organic carbon content in Indian soils is low (0.5 to $0.75 \%)$ it may be due to poor management practices such as lack of addition of crop residues and organic manures or due to the country's intensive cropping system. The results shows that Pusa farms having calcareous soils that contain medium range of organic carbon.

\section{Available nitrogen}

The mineralizable soil nitrogen status of the alluvial soils ranged from low to medium 89.6 to $298.0 \mathrm{~kg} \mathrm{ha}^{-1}$ with mean and SD value of 230.6 and \pm 42.9 respectively. The thematic map of soil mineralizable nitrogen (as shown in Map 5) clearly indicate its spatial distribution, showing an area $86.27 \%$ with available nitrogen content $<250 \mathrm{~kg} \mathrm{ha}^{-1}$ followed by area $13.73 \%$ with available nitrogen $250-500 \mathrm{~kg} \mathrm{ha}^{-1}$. The prevailing high temperature in the region is responsible for rapid burning of organic matter, resulting in low organic carbon content of this soil. Since organic matter contents are an indicator of available nitrogen status, thus the soils of this region are predominantly low in available nitrogen content.

\section{Available phosphorus}

The available phosphorus status of the alluvial soils ranged from low to medium11.78 to $20.79 \mathrm{~kg} \mathrm{ha}^{-1}$ with majority of samples were low in phosphorus content and mean and SD value of 38.12 and \pm 26.24 , respectively. The thematic map of soil available phosphorus (as shown in Map 6) clearly indicated its spatial distribution, showing an area $71.06 \%$ with available 
phosphorus content 25 to $50 \mathrm{~kg} \mathrm{ha}^{-1}$ followed by an area $20.43 \%$ with available phosphorus content $<25 \mathrm{~kg} \mathrm{ha}^{-1}$ and area $8.5 \%$ with available phosphorus content $>50 \mathrm{~kg} \mathrm{ha}^{-1}$.
This low available phosphorus content agricultural field in research area was supplemented by applying phosphorous rich fertilizers accordingly for crops.

Table.1 Mean, range, standard deviation (SD) and coefficient of variation (CV) of thematic map of soil chemical properties and nutrient status

\begin{tabular}{|l|l|l|l|l|l|l|l|l|}
\hline & $\mathbf{p H}$ & $\begin{array}{c}\mathbf{E C} \\
\mathbf{d S} / \mathbf{m})\end{array}$ & $\mathbf{O . C}(\mathbf{\%})$ & $\begin{array}{l}\mathbf{2 A v a i l a b l e} \\
\mathbf{N}(\mathbf{k g} / \mathbf{h a})\end{array}$ & $\begin{array}{l}\text { Available } \\
\mathbf{P}_{\mathbf{2}} \mathbf{O}_{\mathbf{5}}(\mathbf{k g} / \mathbf{h a})\end{array}$ & $\begin{array}{l}\text { Available } \\
\mathbf{K}_{\mathbf{2}} \mathbf{O}(\mathbf{k g} / \mathbf{h a})\end{array}$ & $\begin{array}{l}\mathbf{C a C o 3} \\
(\mathbf{\%})\end{array}$ & $\begin{array}{l}\mathbf{S}(\mathbf{m g} \\
\left.\mathbf{k g}^{-1}\right)\end{array}$ \\
\hline Mean & 8.2 & 0.80 & 0.53 & 230.61 & 38.12 & 156.11 & 29.23 & 9.11 \\
\hline Range & $7.1-$ & $0.12-$ & $0.17-$ & $80.60-298$ & $11.78-$ & $60.11-420$ & $12.5-$ & $0.09-$ \\
& 9.2 & 0.75 & 0.91 & & 207.89 & & 45 & 40.85 \\
\hline S.D & 0.53 & 0.45 & 0.16 & 42.99 & 26.24 & 61.88 & 5.90 & 9.98 \\
\hline C.V & 0.064 & 0.56 & 0.30 & 0.18 & 0.68 & 0.39 & 0.20 & 1.09 \\
\hline
\end{tabular}

Map.1 Grid map (200m X 200m) of Pusa farm

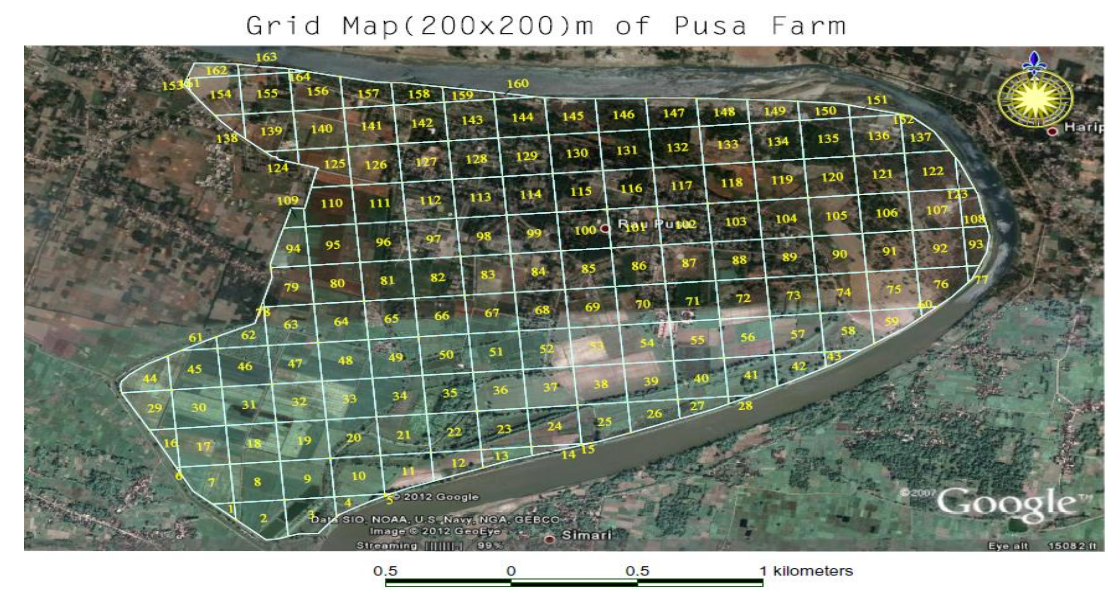

Map.2 Thematic map of Hydrogen ions activity $(\mathrm{pH})$

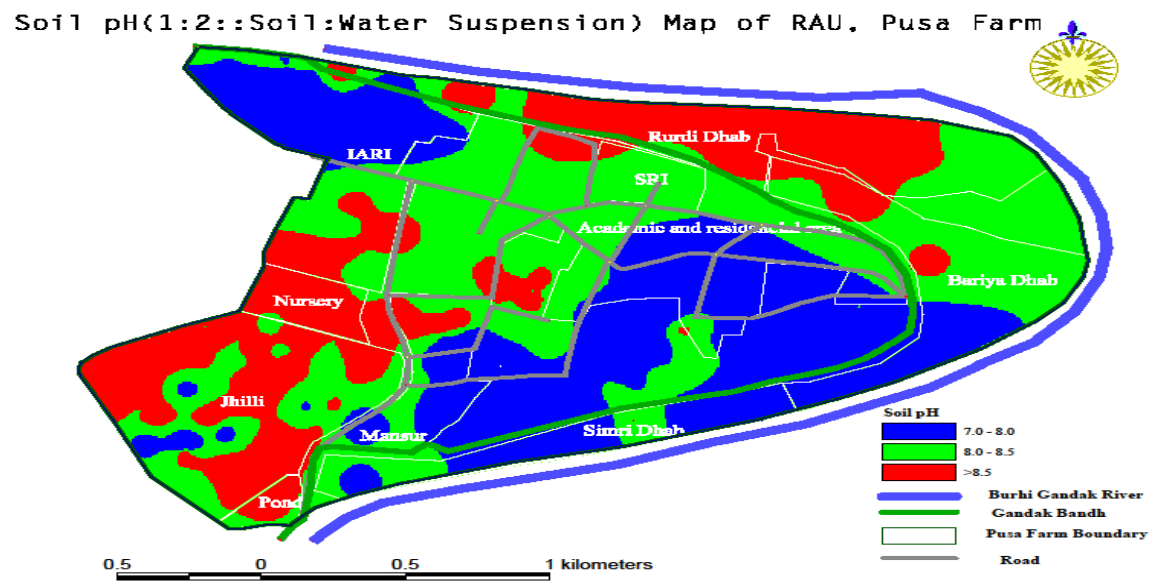


Map.3 Thematic map of soil Electrical conductivity (EC)

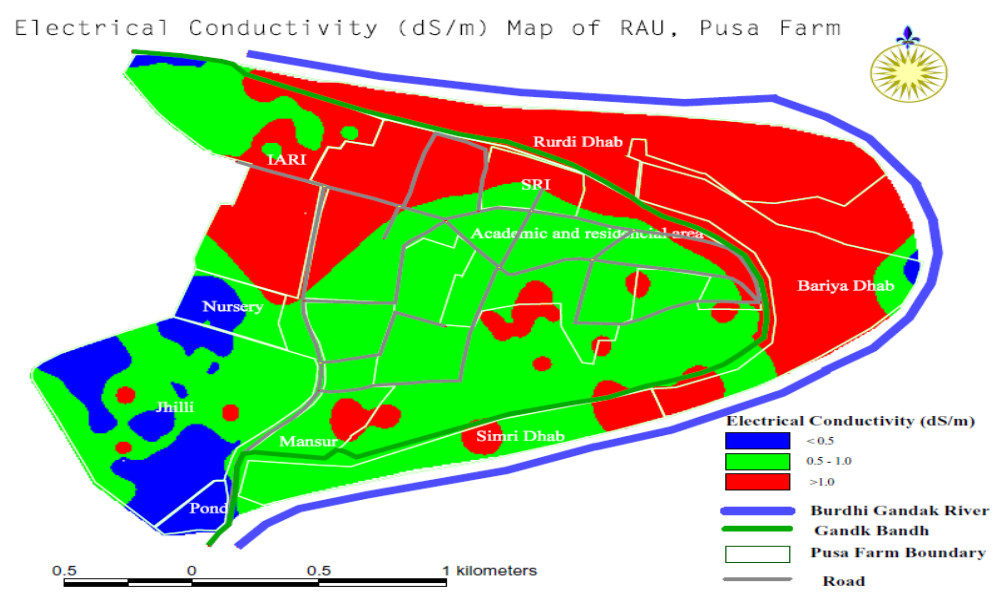

Map.4 Thematic map of soil organic carbon content

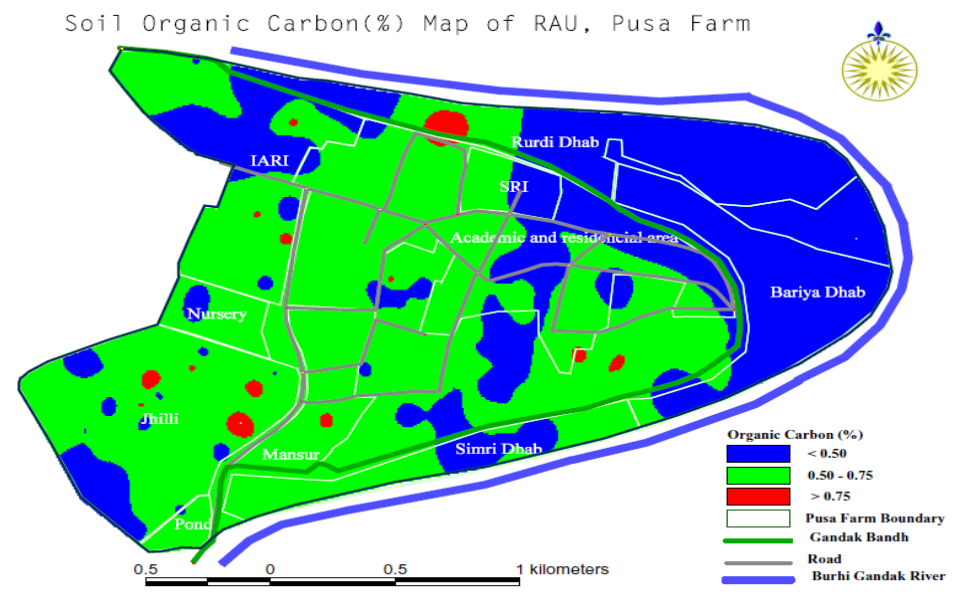

Map.5 Thematic map of soil available nitrogen

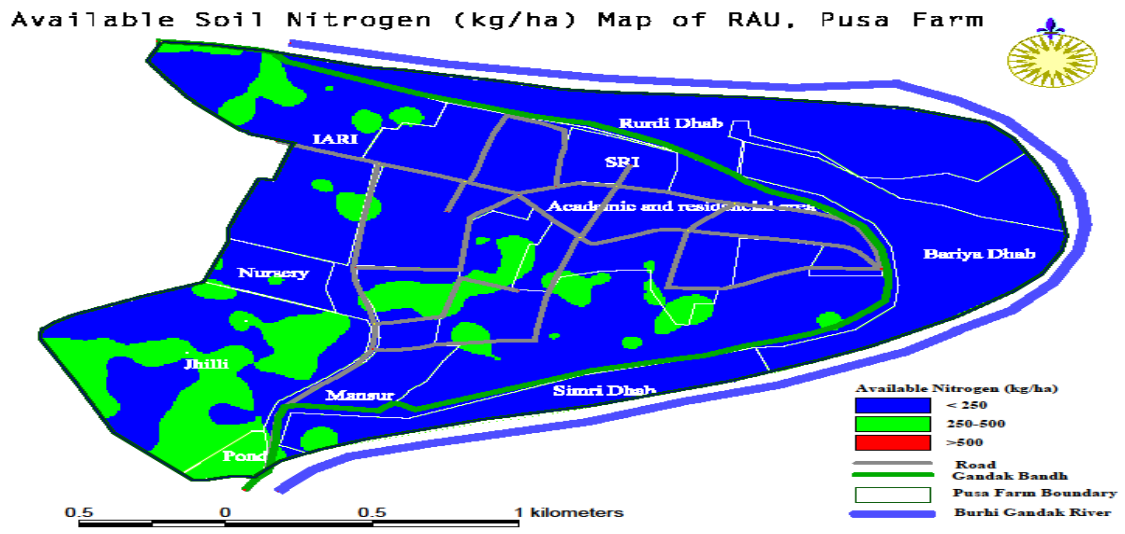


Map.6 Thematic map of soil available phosphorus

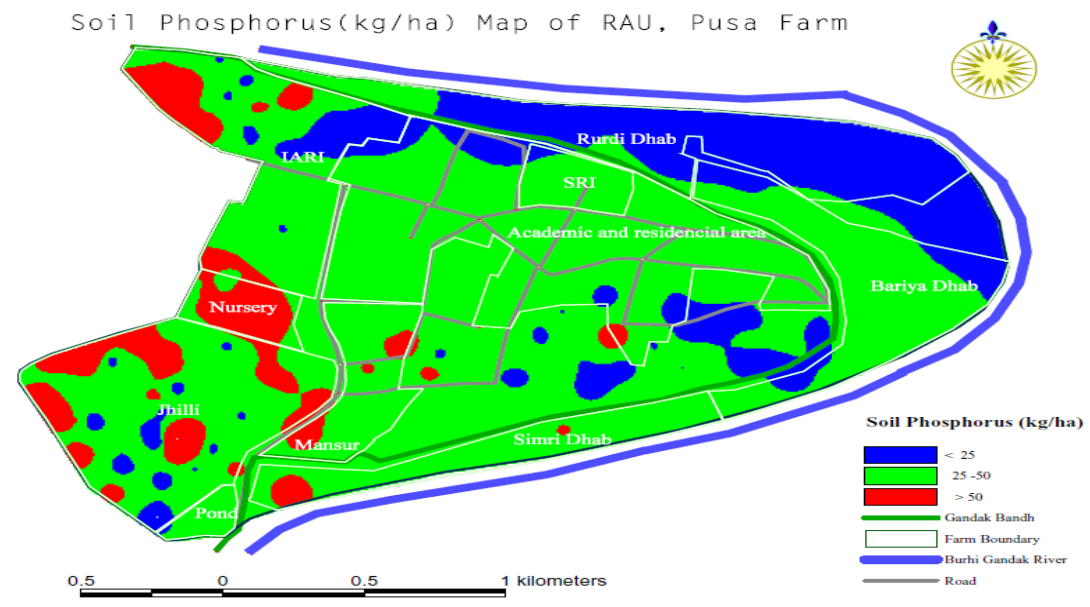

Map.7 Thematic map of soil available potassium

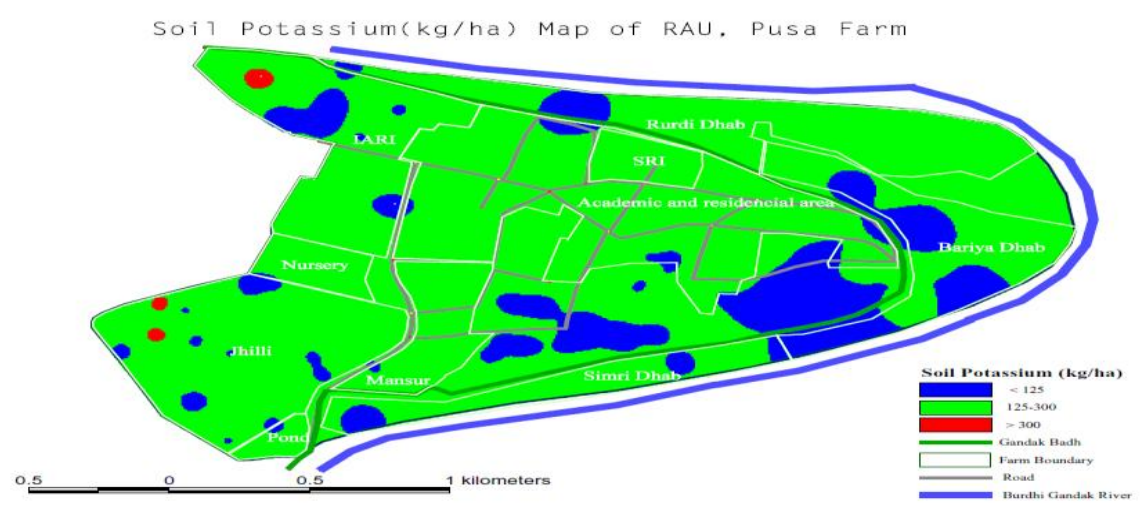

Map.8 Thematic map of soil available sulphur

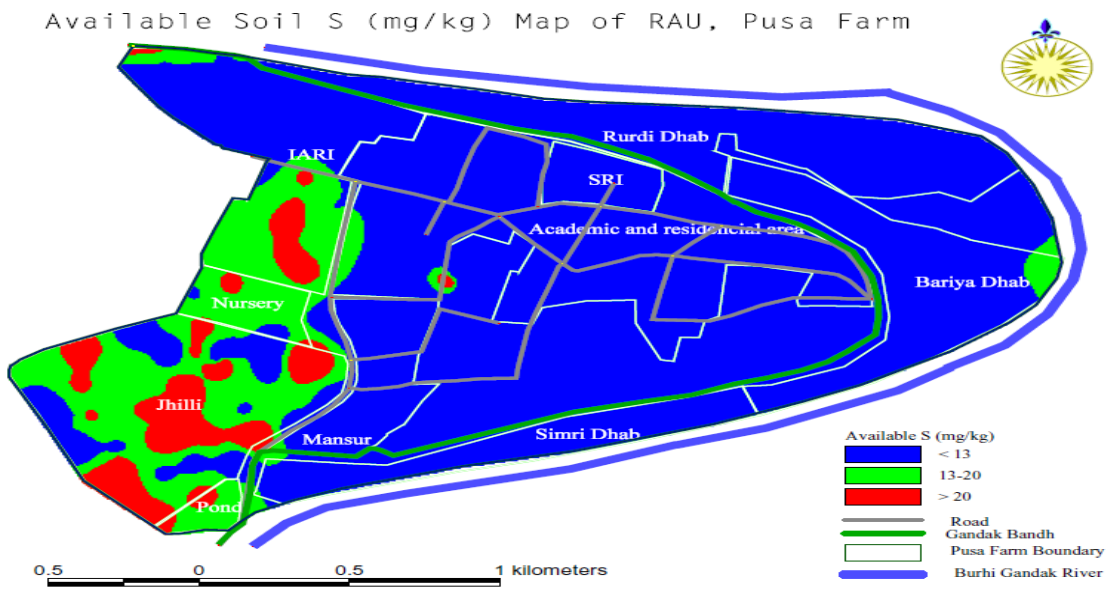


Map.9 Thematic map of soil Free $\mathrm{CaCO}_{3}$

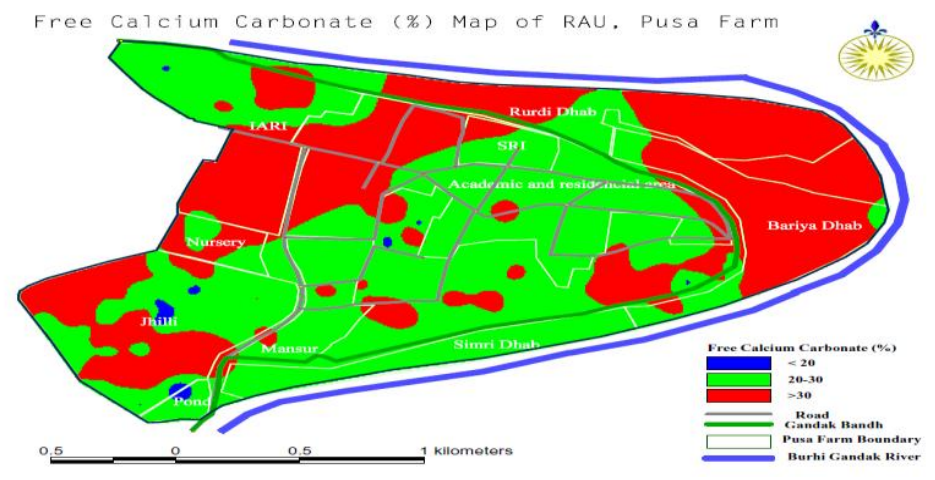

Map.10 Thematic map of Multi major nutrient deficient area

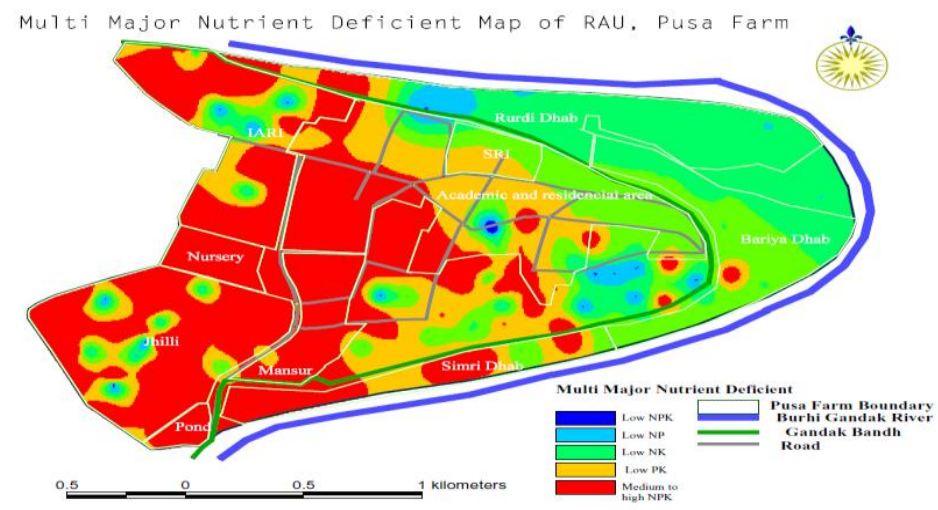

Map.11 Thematic map of Productivity Index (PI)

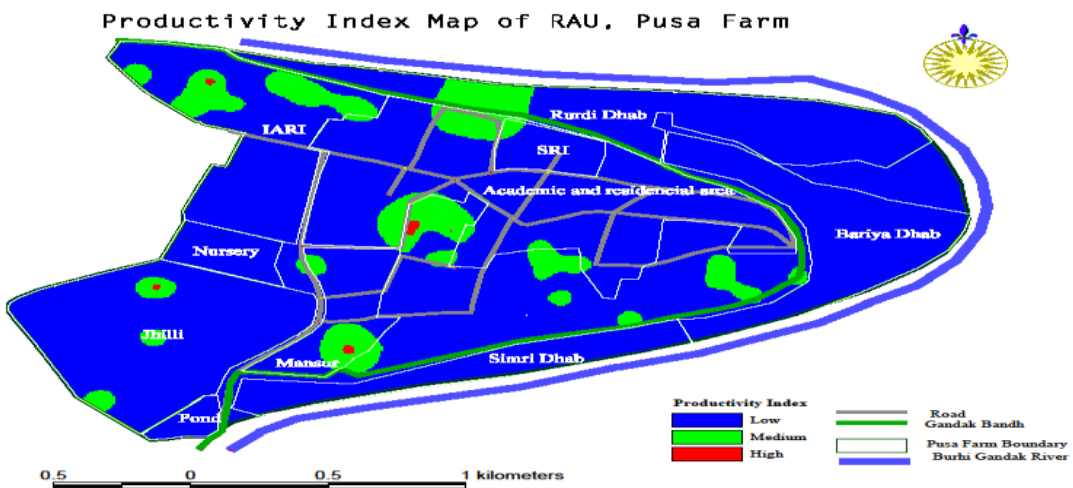

\section{Available potassium}

The available potassium status of the alluvial soils ranged from low to medium 60.48 to 420 $\mathrm{kg} \mathrm{ha}^{-1}$ with mean value of $156.11 \mathrm{~kg} \mathrm{ha}^{-1}$. The thematic soil available potassium map (as shown in Map 7) clearly indicate its spatial distribution, showing largest area $87.71 \%$ with available potassium 125 to $300 \mathrm{~kg} \mathrm{ha}^{-1}$ followed by $14.94 \%$ area with $<125 \mathrm{~kg} \mathrm{ha}^{-1}$ available potassium and $0.31 \%$ area with > $300 \mathrm{~kg} \mathrm{ha}^{-1}$ available potassium. 


\section{Available sulphur}

The available sulphur status of the alluvial soils ranged from low to high0.09- $40.85 \mathrm{mg}$ $\mathrm{kg}^{-1}$ with mean and SD value9.11 and \pm 9.98 respectively. The thematic map of available sulphur (as shown in Map 8) clearly indicates its spatial distribution, showing an area $80.48 \%$ with available sulphur content $<13$ $\mathrm{mg} \mathrm{kg}{ }^{-1}$ followed by area $15.16 \%$ with available Sulphur content $13-20 \mathrm{mg} \mathrm{kg}^{-1}$ and area $4.36 \%$ with available Sulphur content $>20 \mathrm{mg} \mathrm{kg}$. The spatial distribution of available sulphur $<13 \mathrm{mg} \mathrm{kg}^{-1}$ was found in all parts of the study area.

\section{Free calcium carbonate $\left(\mathrm{CaCO}_{3}\right)$}

The value of Free $\mathrm{CaCO}_{3}$ ranged from 12.5 to $43.5 \%$ with mean and SD value 29.19 and \pm 6.82 , respectively. The thematic map of soil Free $\mathrm{CaCO}_{3}$ (as shown in Map 9.) clearly indicates its spatial distribution, showing an area 55.2 \% with Free $\mathrm{CaCO}_{3} \quad 20-30 \%$ followed by area $44.2 \%$ with Free $\mathrm{CaCO}_{3}>$ $30 \%$ and area $0.45 \%$ with Free $\mathrm{CaCO}_{3}<20 \%$.

\section{Multi major nutrient deficient area}

The thematic map of Multi major nutrient deficient area and its spatial distribution in the RAU, Pusa Farm were prepared (Map 10.). Multi major nutrient deficient soils (nitrogen, phosphorus and potassium) were in $40.94 \%$ area located at lowland, medium upland and some part of upland area followed by $36.74 \%$ area with low nitrogen and potassium distributed in most of the upland area and in small patches of medium upland and lowland area. $19.78 \%$ area with low phosphorus and potassium were scattered in lowland and medium upland area. The distribution of $2.45 \%$ area with low nitrogen and phosphorus. Maps of geo-referenced soil sampling sites were generated using TNTmips 2010Individual nutrient ( $\mathrm{P}$ and $\mathrm{K}$ ) maps were prepared and integrated to derive the multimacro nutrient ( $\mathrm{P}$ and $\mathrm{K})$ in the GIS environment.

\section{Productivity Index (PI)}

It was estimated on the basis of soil texture, available $\mathrm{N}, \mathrm{P}_{2} \mathrm{O}_{5}$ and $\mathrm{K}_{2} \mathrm{O}$ showed spatial distribution of $90.27 \%$ area with low PI, 9.57\% area with medium PI and $0.15 \%$ area with high Productivity index. The thematic map (Map 11) of Productivity Index revealed its spatial distribution area in the RAU, Pusa Farm. The productivity class for each soil unit was determined according to the PI values and attributes were assigned after generation of maps in TNTmips. The Zone with values of PI < 40 were rated as low productivity class, 41-60 as medium, 61-80 as high and $>80$ as very high.

The nutrient index, i.e., a single index (weighted average) showing an area's overall fertility status, was calculated (Parker et al., 1954)for the major nutrients i.e., nitrogen, phosphorus and potassium were $1.416,1.893$ and 1.678 , respectively, indicating over all low nitrogen status, while phosphorus and potassium were in medium range in the study area.

\section{References}

Saldana A, Stein A and Zinck JA 1998. Spatial variability of soil properties at different scales with in three terraces of the Henare River (Spain). Catena33: 139-153.

Mc Grath D and Zhang C S 2003.Spatial distribution of soil organic carbon concentrations in grassland of Ireland. Applied Geochemistry18: 1629-1639.

Sepaskhah A R, Ahmadi S H and NikbakhtShahbazi A R2005. Geostatistical analysis of sorptivity for a soil under tilled and no-tilled 
conditions. Soil and Tillage Research, 83: 237-245.

Liu D W, Wang Z M, Zhang B, Song K S, Li X Y, Li J P, Li F and Duan H T2006. Spatial distribution of soil organic carbon and analysis of related factors in croplands of the black soil region, Northeast China. Agriculture Ecosystems and Environment, 113: 73-81.

Matheron G 1963. Principles of geostatistics. Economic Geology, 58: 1246-1266.

Webster R and Oliver M 2001. Geostatistics for environmental scientists. $\mathrm{R}$ Webster, MA Oliver - 2007 - books. google.com John Wiley and Sons, Chichester

Bradshaw T K, Muller B 1998. Impacts of rapid urban growth on farmland conversion: application of new regional land use policy models and geographical information systems. Rural Sociology, 63: 1-25.

Wang Z M, Zhang B, Zhang S Q, Li X Y, Liu D W, Song K S, Li J P, Li F and Duan H T 2006. Changes of land use and of ecosystem service values in Sanjiang Plain, Northeast China. Environmental Monitoring and Assessment, 112: 69-91.

McGrath D and Zhang C S2003.Spatial distribution of soil organic carbon concentrations in grassland of Ireland. Applied Geochemistry18: 1629-1639.

Singh A P, Singh R R, Pronad J and Ghanshyam (2006) Laboratory manual for soil-Plant-water analysis, Deptt. of Soil Science, RAU, Bihar, Pusa, Samastipur.

Oades J M 1988. The retention of organic matter in soils, Biogeochemistry, 5: $35-70$,

Parker F W, W L, Nelson E Winters and J E Miles 1951. The broad interpretation and application of soil test summaries. Agron. J43: 103-112

Pandey A K 2012.Long-term effects of organic and inorganic fertilizers on the distribution, transformation and nutrition of sulphur, zinc and boron in calcareous soil. M.Sc. Dept. of soli science Thesis. Rajendra Agricultural University, Bihar, Pusa.

Riquier J D, Luis B and Cornet J P (1970) A System for Soil Appraisal in Terms of Actual and Potential Productivity," Soil Resource Development and Conservation Service, Land and Water Development Division, pp. 135.

Rupali 2014. Screening of maize varieties to zinc stress in calcareous soil. M.Sc. Thesis. Dept. of soil science. Rajendra Agricultural University, Bihar, Pusa.

SwetaNekee 2014. Long-term effects of organic and inorganic fertilizers application on phosphorous transformation under Rice-Wheat cropping system in calcareous soil. M.Sc. Thesis. Dept. of soli science. Rajendra Agricultural University, Bihar, Pusa.

\section{How to cite this article:}

Hena Parveen, M. P. Singh, S. S. Prasad, Ajeet Kumar, Dhanajay Kumar, Raju Kumar and Sunil Kumar. 2020. Spatial Variability Mapping of Soil Nutrient Through Geo-informatics Technology. Int.J.Curr.Microbiol.App.Sci. 9(11): 891-900. doi: https://doi.org/10.20546/ijcmas.2020.911.107 